\title{
NLRC5 wt Allele
}

National Cancer Institute

\section{Source}

National Cancer Institute. NLRC5 wt Allele. NCI Thesaurus. Code C132032.

Human NLRC5 wild-type allele is located in the vicinity of $16 q 13$ and is approximately 94 $\mathrm{kb}$ in length. This allele, which encodes protein NLRC5, plays a role in signaling, immunity and antiviral processes. 